\title{
Treating the Digital Disease: The Role of Digital and Physical Primary Sources in Undergraduate Teaching
}

\begin{abstract}
In early 2019, a Yale University research team composed of librarians and staff from the Poorvu Center for Teaching and Learning engaged in an Ithaka $S+R$ study investigating the teaching needs of instructors using primary sources at the undergraduate level in the humanities and social sciences. After interviewing instructors and analyzing the results, the Yale team issued a report describing motivations for teaching with primary sources, how such sources are incorporated into classroom pedagogy, and challenges identified by the interviewees. In this article, I examine the particular meanings assigned to physical and digital primary sources by the instructors interviewed, and why physical primary sources continue to resonate with faculty in an overwhelmingly digital world. The COVID-19 pandemic has radically altered the primary source landscape, unsurprisingly accelerating the use of digital primary sources while leaving the role of physical collections in teaching in an uncertain territory.
\end{abstract}

\section{Introduction}

Beginning in March 2019, Yale University Library (YUL) and the Yale Poorvu Center for Teaching and Learning embarked, with 26 other institutions in the United States and the United Kingdom, in an Ithaka S+R study investigating the teaching support needs of instructors working with primary sources at the undergraduate level in the humanities and humanities-leaning social sciences. ${ }^{1}$ Ithaka $S+R$ is a nonprofit organization that "work[s] with leaders in higher education, academic libraries, museums, foundations, and publishers to research, evaluate, and provide strategic guidance in a range of areas." 2 Throughout fall 2019, members of the research team interviewed 15 instructors engaged in using primary sources to teach undergraduates at Yale, following a rubric developed by Ithaka $S+R$ staff members.

1. Danielle Cooper and Rebecca Springer, "Announcing a New Project on Teaching with Primary Sources," Ithaka S+R Blog, posted January 16, 2019, https://sr.ithaka.org/blog/announcing-a-newproject-on-teaching-with-primary-sources/.

2. “Our Work," Ithaka S+R, accessed August 30, 2020, https://sr.ithaka.org/our-work/. 
In this article, I present some initial findings relating to use of digital and physical materials in the classroom from instructor interviews conducted at Yale University in fall 2019 as part of the larger Ithaka S+R study. Through these findings, I analyze the reasons why teaching with physical primary sources continues to resonate with instructors who have access to special collections, often in dialogue and in juxtaposition with the millions of digitized rare materials most often used in research and teaching. ${ }^{3}$ In an increasingly digital world, instructors value students having physical access to rare materials and special collections. With COVID-19 circulating, instructor and student connections to the physical collections are tenuous and in a state of flux as health and safety protocols, as well as an accelerated push toward digitized materials, change the ability and need to lay hands on objects.

\section{Methods}

Following Yale IRB review and approval of the study parameters and interview questions designed by Ithaka $S+R$, the Yale research team began its work in late summer 2019. Investigators for the Yale study, in consultation with several groups within YUL and the Poorvu Center, identified nearly 50 instructors for possible interviews. ${ }^{4}$ When considering potential interview participants, the interviewers looked at faculty rank, years of teaching, and subject specialties, eventually assembling a pool of 15 instructors bringing diverse perspectives to the interviews. Interviews were conducted from October to December 2019. Most interview participants actively use the physical special collections at Yale in their teaching, holding classes in secure classrooms for "hands-on" teaching, sometimes in com-

3. In her 2012 article, Jenny Newell points out, "[s]ince the main uptake of digital technologies by cultural institutions has occurred during the last two decades, the effects of digitization in this context, and the relationship between digital and 'real' collections, have only recently become objects of concerted scholarly attention." Jenny Newell, "Old Objects, New Media: Historical Collections, Digitization and Affect," Journal of Material Culture 17, no. 3 (2012): 288. She refers to this edited volume as an example: Fiona Cameron and Sarah Kenderdine, eds., Theorizing Digital Cultural Heritage: A Critical Discourse (Cambridge, MA: MIT Press, 2007). In a recent white paper, Brianna Gormly, Maura Seale, Hannah Alpert-Abrams, Andi Gustavson, Angie Kemp, Thea Lindquist, and Alexis Logsdon discuss the place of digital primary sources in larger literacy schemas, describe how scholars, particularly historians, see and evaluate digital primary sources against physical primary sources, and offer methods of teaching with digital materials. See Brianna Gormly, Maura Seale, Hannah Alpert-Abrams, Andi Gustavson, Angie Kemp, Thea Lindquist, and Alexis Logsdon, "Teaching with Digital Primary Sources: Literacies, Finding and Evaluating, Citing, Ethics, and Existing Models," \#DLFteach, posted October 17, 2019, https: / / doi.org/10.21428/65a6243c.6b419f2b.

4. Investigators for the Yale study were the author; David Hirsch, Director for Educational Technology Strategy, Poorvu Center for Teaching and Learning; Bill Landis, Associate Director for Public Services, Manuscripts and Archives; and Sara Powell, Research Librarian, Beinecke Rare Book \& Manuscript Library. Sara Powell left Yale University in February 2020 for the new position of Assistant Curator of Early Books and Manuscripts at Houghton Library, Harvard University. For access to the entire Yale report, including interview questions and the breakdown of faculty rank and department, please see Melissa Grafe, David Hirsch, Bill Landis, and Sara Powell, "Support Services at Yale University for Teaching with Primary Sources: An Exploration of Instructor Rationales and Needs," Yale University Library Staff Publications 13, (2020), https:/ / elischolar.library.yale.edu/yul_staff/13/. 
bination with digital primary sources available through YUL and elsewhere. Many participants have strong relationships with the library, either as users of library collections, or through librarians, curators, and library staff.

Interviews were recorded digitally, and, once the interviews were completed, the audio recordings were sent out to a vendor for transcription. The Yale project team used an open coding methodology, following the Ithaka protocol for the study, to code the interviews using CATMA (Computer Assisted Text Markup and Analysis), a free, open-source coding program. Each interviewer read all the transcripts to develop a joint tag set, which each interviewer then applied through another indepth reading of all the interviews. Tagged text from the interviews was extracted in spreadsheets for review, and the research team used Google Docs and Forms for additional work on the project.

\section{Learning to Teach with Primary Sources}

Throughout the interviews, instructors discussed how they learned to teach with primary sources. They also talked about their interactions with students in the classroom, their beliefs and assumptions underlying their pedagogy, and their reasons for using primary sources as a critical part of their work in the classroom. They provided examples of syllabi and assignments, pointing out the many ways primary sources shaped student learning. Often, participants described primary sources in relation to special collections, particularly the wealth of rare materials in various Yale archives, libraries, and museums. They also discussed how library staff facilitated these interactions with setup of primary source sessions, with librarians and curators helping to identify objects or providing specialized knowledge on materials or topics during the class.

While training is often an integral part of many jobs, interviewees indicated that learning to teach with primary sources came primarily from their own experiences learning from primary sources, not from any actual formal training. As one participant stated, "No one ever said, 'Here, we're going to learn now how to teach from primary sources."'5 This refrain was present throughout multiple interviews. Most interviewees indicated they were never formally trained, and past experiences shaped the way they teach with primary sources today.

Study participants often experienced primary source teaching as undergraduate and graduate students themselves. Many described sessions where they were exposed to physical primary source materials, often rare or "special," and discussed the impact of that interaction. Others mentioned that the ways their mentors

5. Grafe et al., "Support Services at Yale University for Teaching with Primary Sources," 10. 
taught primary sources to them as students carried into their own pedagogical approaches at Yale. As one participant noted, "Some of the materials I use with my students now are based on sort of exercises I was given and the ways I was taught [at undergraduate institution]... I feel like my instruction there was sort of really, really excellent in terms of how to sort of actively use, interrogate, contextualize primary source documents."' These experiences at the undergraduate and graduate level play a role in the way instructors teach with primary sources, including the differences perceived between using digital or physical materials in the classroom.

\section{Digital Primary Sources and the Role of Physical Objects in Teaching}

A thread passing through these interviews focuses on the interplay between digital and physical primary sources. Some interviewees considered digital primary sources as a supplement to in-person interactions with material in the classroom. Others centered digital primary sources in their courses, mainly large lectures, using, as one instructor termed it, a "Power[P]oint method of teaching." 7 In this mode of teaching, the lecturer uses digitized primary sources in a PowerPoint slide deck as talking points or for illustrative purposes during the lecture. For discussion sections, professors often had students access digitized primary sources, usually provided by the library, through a learning management system like Canvas. These types of interactions with digitized collections are a familiar use of digital materials in teaching institutions throughout the world. Instructors and students rely heavily on digital materials for their own research, borne out by usage statistics from various databases and studies tracking the research habits of humanities scholars. ${ }^{8}$ Digital primary sources appear in various parts of teaching, whether on the screen in lectures, in the course management system, as part of discussion sessions, or in research assignments.

Several instructors discussed the value they placed on materiality and strongly desired that students have physical interaction with the objects during class time. As an art historian argued, "I can't teach the difference between a woodcut or engraving, or the difference between a manuscript on parchment and a book on paper, from a digital object. I can't teach scale. These are essential categories of visual analysis. So one of the reasons I give visual analysis assignments in front of objects in the classrooms is precisely to be like, there's information you cannot get from a

6. Grafe et al., "Support Services at Yale University for Teaching with Primary Sources," 11.

7. Grafe et al., "Support Services at Yale University for Teaching with Primary Sources," 13.

8. See, for example, Alexandra Chassanoff, "Historians and the Use of Primary Source Materials in the Digital Age," American Archivist 76, no. 2 (Fall/Winter 2013): 458-80; Hieke Huistra and Bram Mellink, "Phrasing History: Selecting Sources in Digital Repositories," Historical Methods: A Journal of Quantitative and Interdisciplinary History 49, no. 4 (2016): 220-29. 
digital image." The ability to turn pages, feel texture, understand scale, work an instrument, and analyze other information embedded into physical objects was described by many interviewees as an integral part of the research process and part of learning the discipline. Digital objects lacked some of this tactile data.

Participants also talked about their efforts to show students the importance of "serendipity" and "immersion" that often happens when diving into a physical archival collection, opening a box and literally paging through files. ${ }^{10}$ Instructors did not describe digital archives in the same way, or at all. The construction of such archives may not be as visible online, and the digital archive, scanned from physical originals, does not seem to have the same element of surprise or immersive experience. In a 2013 article examining photographic archives, Martha Sandweiss discusses how difficult it is to know how much of a physical archive is online, and how the decision-making process from physical to digital archives is often invisible to the user. Sandweiss further points out, "Digital archives tend to erase all signs of their own creation. They convey the illusion of providing researchers with access to everything. But they rarely do."11 For instructors in the Yale study, digital archival sources did not elicit the same kind of immersive or serendipitous response as having physical archival boxes in front of students in the classroom.

There was one larger, and surprising, reason why some instructors continue to value the physical primary source. One interviewee put it best: "We're at a moment where the desire for a tangible, haptic encounter with something is understood to be an antidote to something that is perceived to be unhealthy in our society, which is the extent to which we reside in the digital sphere." ${ }^{12}$

This underlying concern about the overwhelming nature of our digital lives came out in various ways throughout the interviews. As one of my co-authors noted, "Many participants commented that undergraduates today are at risk 'of becoming largely immaterial disembodied citizens,' interacting solely with digital objects lo-

9. Grafe et al., "Support Services at Yale University for Teaching with Primary Sources," 13. For a discussion on the intersections and tensions between art history and material culture studies, and the move toward visual culture analysis, see Michael Yonan, "Toward a Fusion of Art History and Material Culture Studies," West 86th: A Journal of Decorative Arts, Design History, and Material Culture 18, no. 2 (2011): 232-48.

10. There is a large literature related to serendipity in archives and special collections, through e-books and in other digital spaces. See, for example, Wendy M. Duff and Catherine A. Johnson, "Accidentally Found on Purpose: Information-Seeking Behavior of Historians in Archives," Library Quarterly 72, no. 4 (2002): 472-96; Elizabeth B. Cooksey, "Too Important to Be Left to Chance: Serendipity and the Digital Library," Science \& Technology Libraries 25, no. 1 (2004): 23-32; Michael H. Hoeflich, "Serendipity in the Stacks, Fortuity in the Archives," Law Library Journal 99, no. 4 (2007): 813-27.

11. Martha A. Sandweiss, "Artifacts as Pixels, Pixels as Artifacts: Working with Photographs in the Digital Age," Perspectives on History 51, no. 8 (November 2013), https:/ / www.historians.org/publications-and-directories/perspectives-on-history/november-2013/artifacts-as-pixels-pixels-as-artifacts.

12. Grafe et al., "Support Services at Yale University for Teaching with Primary Sources," 9. 
cated through digital searches, and communicating their views primarily in virtual forums." 13 These descriptors of the digital realm, the "immaterial, disembodied citizens" and the "unhealthy" aspects living in a digital world, evoke, in a metaphor for a COVID-19 world, fears of a digital disease. While having experiences with physical materials may not be the only "antidote" for an overwhelmingly digital life, instructors felt strongly that contact with physical primary sources brought students out of the largely digital realm of academic learning.

The value instructors place in teaching with physical access to objects, particularly rare materials, bears out in the statistics on Yale class use gathered among eight special collections, primarily libraries, on campus. From July 2018 to June 2020, there were approximately 1,609 Yale class sessions taught with special collections materials, not including sessions for non-Yale groups, tours, or other one-off events. Nearly all the class sessions in special collections use physical objects, but they may also include a digital component, including time with librarians reviewing ways to conduct online research in conjunction with the physical collections in the classroom. Despite the large number of special collections sessions at Yale, the majority of research material for classes swings heavily toward digital resources, with thousands of subscription and openly accessible databases and millions of digitized objects available through YUL and the internet more broadly, in online repositories like HathiTrust, Internet Archive, the Digital Public Library of America, and many more. Like many academic libraries across the United States, YUL invests more in subscription databases and, increasingly, open access collections than in print collections. The exception to this is Yale's special collections, which continue to acquire mainly physical rare material, although there has been growing acquisitions and infrastructure development around digitized and born digital collections. Instructors in the Yale study regularly pointed to the sheer wealth and variety of primary source material, online and physical, as an important reason to take advantage of the opportunities to use these sources in teaching undergraduate students.

\section{Conclusion}

When COVID-19 hit the United States in early 2020, access to physical library collections, including special collections, archives, and museums, dried up for millions of people across the country. The cascade of sudden closures across academic institutions created a massive scramble among libraries and other cultural sites to provide digital access to collections in any way possible. Digital repositories and aggregators HathiTrust and Internet Archive activated "emergency" libraries, opening up temporary access to millions of digitized books, journals, and other objects

13. David Hirsch, from Grafe et al., "Support Services at Yale University for Teaching with Primary Sources: An Exploration of Instructor Rationales and Needs," 7. 
usually inaccessible online due to copyright. Instructors turned to online teaching, learning how to use platforms like Zoom while frantically changing syllabi and assignments based on access to online research collections as students faced challenges trying to learn at home, including uneven access to the internet. This pandemic disease accelerated the use of digital surrogates and restructured access for researchers and instructors who use physical library collections in ways that are still playing out.

While materiality still matters to instructors at Yale, use of physical primary source materials is now heavily mediated by public health and safety mandates, as well as the use of technology. Library staff follow new workflows when providing access to physical collections, including item quarantine and hands-off delivery and pickup of materials. Special collections are open by appointment to keep the number of researchers in reading rooms down to mandated levels, and short-term visitors and researchers outside the Yale community are not allowed on campus. These policies, which help to reduce the risk of visitors bringing COVID-19 on campus and reduce occupant density in library spaces to minimize the virus's spread, have greatly reduced the number of individuals using special collections in person. Use of physical special collections by the Yale community has also plummeted, driven not only by COVID-19 restrictions and concerns, but by a new policy adopted by the YUL special collections community of digitizing materials for teaching and research purposes. Recognizing that the larger Yale and research community, based all over the world, face COVID-19 travel restrictions, special collections units across YUL currently prioritize access through digitization.

Instructors are primarily using digital materials in online teaching. While some students are on campus, others are based throughout the United States or in other parts of the world, and classes are, for the most part, entirely remote. ${ }^{14}$ Professors, aware of the inequities students face in a variety of family and life situations during the pandemic, design assignments that incorporate digitized primary sources, although students can still access physical library materials on Yale's campus and have nonrare books sent directly to their homes. Several professors, librarians, and curators are working with physical special collections via document scanners and cameras for classes in a hybrid digital/physical primary source approach. This approach provides some sense of the physical item and conveys aspects of a primary source not always apparent in the digitized version, but it lacks the material engagement the professors strongly feel is so important to students. There are limitations using a document camera, particularly around oversized items, but the camera does provide a shared view of material to the class that is impossible to

14. Please see the July 1, 2020, message from Yale President Peter Salovey, outlining the parameters of the fall semester: https:// covid19.yale.edu/community-messages/fall-2020/. 
achieve by physically crowding around or engaging with an object. Teaching during COVID-19 has pushed instructors and library staff to try new and different types of digital pedagogy, something that was never a major part of Yale classes before, and the hope is that these innovations are creating opportunities for new kinds of learning using primary sources. ${ }^{15}$

15. Building on the initial teaching with primary sources study in 2019-2020, Ithaka $S+R$ began a follow-up study in early 2021 funded by The Andrew W. Mellon Foundation on "how teaching and learning with cultural heritage collections and materials is evolving in response to the pandemic." For more information about this study, which certainly relates to some of the pandemic responses described above, please see the blog post: https://sr.ithaka.org/blog/teaching-with-cultural-heritage-onlineduring-the-pandemic/. Ithaka released the final report on teaching with primary sources as this article was going into publication. See Kurtis Tanaka et al., "Teaching with Primary Sources: Looking at the Support Needs of Instructors," Ithaka S+R, 23 March 2021, https:// doi.org/10.18665/sr.314912.

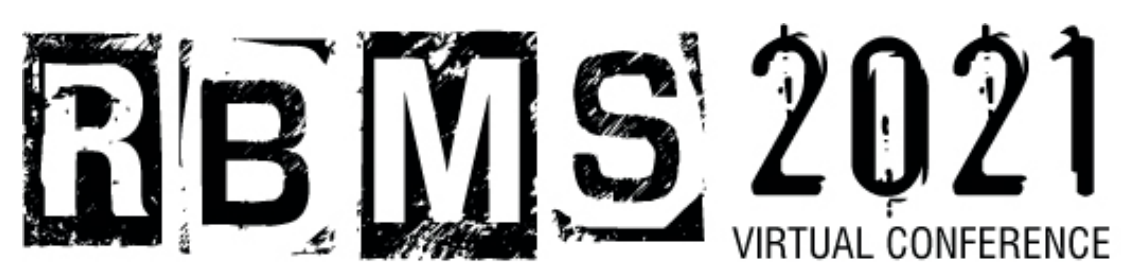

\section{RBMS 2021 Virtual Conference (\#rbms21) POWER, RESISTANCE, AND LEADERSHIP} JUNE 8-10, 2021

Thanks to the over 350 of you that have already registered for the RBMS 2021 Virtual Conference. There's still time to join us as we critically examine the existing power structures that have shaped and continue to impact special collections and archives. This conference will explore the power dynamics within our profession and the ways in which we experience, exert, and/or defy power. Come hear stories of resistance, large and small, successful or not. Learn practical tools and strategies, and explore thought-provoking ideas. We hope you will be inspired to help make transformative changes in our field! 